\title{
PREDICTION OF AXIAL CAPACITY OF PILES DRIVEN IN NON-COHESIVE SOILS BASED ON NEURAL NETWORKS APPROACH
}

\author{
Amel BENALI ${ }^{\mathrm{a}}$, Bakhta BOUKHATEM ${ }^{\mathrm{b}}$, Mahmoud N. HUSSIEN ${ }^{\mathrm{c}}$, \\ Ammar NECHNECH ${ }^{\mathrm{d}}$, Mourad KARRAY \\ a, dDepartment of Civil Engineering, University of Science and Technology, Houari Boumediene, Algiers, Algeria \\ $b, c, e$ Department of Civil Engineering, Faculty of Engineering, Sherbrooke University, Sherbrooke, QC, Canada \\ ${ }^{c}$ Department of Civil Engineering, Faculty of Engineering, Assiut University, Assiut, Egypt
}

Received 12 May 2015; accepted 20 Oct 2015

\begin{abstract}
This paper presents an application of two advanced approaches, Artificial Neural Networks (ANN) and Principal Component Analysis (PCA) in predicting the axial pile capacity. The combination of these two approaches allowed the development of an ANN model that provides more accurate axial capacity predictions. The model makes use of Back-Propagation Multi-Layer Perceptron (BPMLP) with Bayesian Regularization (BR), and it is established through the incorporation of approximately 415 data sets obtained from data published in the literature for a wide range of uncemented soils and pile configurations. The compiled database includes, respectively 247 and 168 loading tests on largeand low-displacement driven piles. The contributions of the soil above and below pile toe to the pile base resistance are pre-evaluated using separate finite element (FE) analyses. The assessment of the predictive performance of the new method against a number of traditional SPT-based approaches indicates that the developed model has attractive capabilities and advantages that render it a promising tool. To facilitate its use, the developed model is translated into simple design equations based on statistical approaches.
\end{abstract}

Keywords: neural networks, principal components analysis, failure zone, ultimate capacity, pile load tests, FE, SPT.

\section{Introduction}

Pilling has been used for many years as a common foundation solution for different types of civil structures. A large number of design approaches, therefore, have been proposed to predict the ultimate capacities of piles. These approaches range from simple empirical formulations to more sophisticated finite element (FE) analyses, with new methods introduced every few years (Iskander 2011). In practice, the ultimate pile capacity has been customary estimated based on correlations with other in situ tests such as the standard (SPT) and the cone (CPT) penetration tests (Bandini, Salgado 1998; Shariatmadari et al. 2006). However, the interdependency of the factors involved such as soil stratifications, soil-pile interaction, and distribution of soil resistance along the pile shaft implicate a considerable level of uncertainty and may obstacle the implementation of simple regression analyses, and demands more extensive and sophisticated approaches to ensure an appropriate structural and serviceability performance.

Alternatively, artificial neural networks (ANNs) have been used recently to predict the ultimate capacity of driven piles based on in situ tests (e.g., Shahin 2014;
Kordjazi et al. 2014; Azizkandi et al. 2014; Mohammad et al. 2015). However, most of ANNs models available in the literature generally used a limited number of data sets and fewer models were developed based on more accurate measurements of soils properties from the SPT or CPT results. Moreover, the applicability of most of these models was limited to large-displacement driven piles. Yet, little work has been devoted to predict the capacity of low-displacement piles.

On the other hand, several researchers used the ANN approach for the development of more sophisticated and integrated systems in conjunction with other techniques such as evolutionary computation and probabilistic techniques (e.g., Boukhatem et al. 2011; Alkroosh, Nikraz 2012; Ismail et al. 2013; Ahangar-Asr et al. 2014). Nevertheless, only a few investigations were carried out on the application of a practical technique and intelligible manipulation for data analysis before learning an ANN model which may contain redundancies and correlations between them. This represents a very important step before designing a model. The Principal Component Analysis (PCA) is then used and considered as a statistical tool

Corresponding author: Amel Benali

E-mail: benali_amel4@yahoo.fr 
for the elimination of correlations between the data as well as reducing the representation size of these data or data compression (Bellamine, Elkamel 2008; Boukhatem et al. 2012).

In this study, two techniques, the ANN and PCA are compiled to develop a new model that would be able to predict the ultimate capacity of both low- and large-displacement driven piles embedded in un-cemented soils based on SPT data. Separate Finite Element (FE) analyses were also conducted to examine the relative contribution of the soil above and below the pile toe to its ultimate capacity. The performance parameters of the developed model are compared successfully with those obtained from field tests as well as from reliable approaches. In addition, a sensitivity analysis or generalization ability of the developed model is carried out to evaluate the influence of input parameters on the model outputs.

\section{Contribution of N-SPT above and below the pile tip to the end-bearing pile resistance}

\subsection{Basic state of knowledge on SPT}

The Standard Penetration Test (SPT) is one of the oldest and most common in situ tests used for soil exploration, because of its simplicity, low cost, and versatility. The recorded SPT count blows, $N$ value is widely accepted to be corrected to a standard dynamic energy of $60 \%$ of the hammer potential energy (Skempton 1986) using:

$$
N_{60}=N \cdot \frac{E_{m} \cdot C_{B} \cdot C_{S} \cdot C_{R}}{0.60},
$$

where: $N_{60}$ is the SPT $N$-value corrected for field procedures and apparatus; $E_{m}$ is the hammer efficiency; $C_{B}$ is the borehole diameter correction; $C_{S}$ is the sample barrel correction; and $C_{R}$ is the rod length correction. The effect of overburden pressure, $\sigma_{v}^{\prime}$ on $N_{60}$ value is commonly corrected as:

$$
N_{1(60)}=N\left(P_{a} / \sigma_{v}^{\prime}\right)^{0.25},
$$

where: $P_{a}$ is a $100-\mathrm{kPa}$ reference effective pressure.

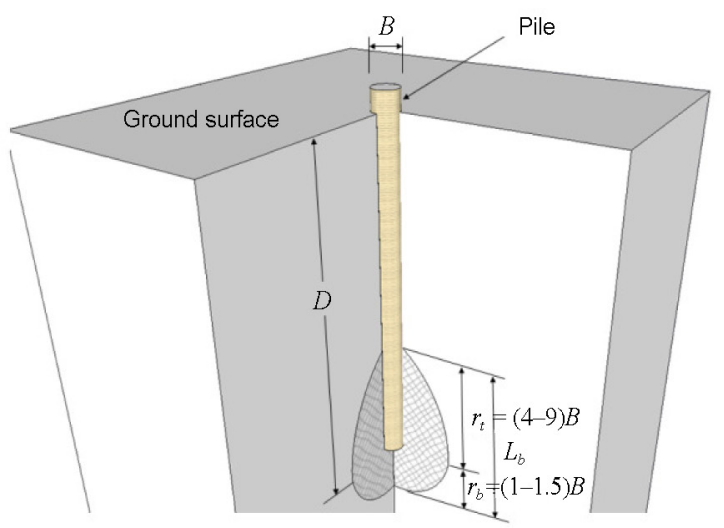

Fig. 1. Schematic view of spiral logarithmic failure surface around the base according to Eslami and Fellenius (1997)
Estimating the end-bearing pile resistance from SPT data requires the definition of the failure zone around the pile tip as it specifies the range in which the $N$ trace considered in estimating the average $\bar{N}_{b}$ value. In this context, many investigators proposed failure mechanisms to estimate the ultimate point resistance of single driven piles in sand (e.g., Das 1984; Nguyen et al. 1991 among others). In particular, Eslami and Fellenius (1997) proposed a model in which the local failure is defined as a spiral logarithmic surface starting at the pile tip, and ending at a point on the pile shaft (Fig. 1). For simplicity, Eslami and Fellenius (1997) adopted an influence zone extending from $4 B$ below the pile base to a height of $8 B$ above. This influence zone is, in fact, consistent with experimental studies by Meyerhof (1976), Shariatmadari et al. (2006), and Faizi et al. (2015).

In fact, the error in evaluating the contributions of these zones is one of the major sources of the inconsistency of the capacity values obtained from different traditional methods. To investigate the relative contribution of these zones (Fig. 2, where $\alpha$ and $\beta$ represent, respectively, the range of the zones above and below the pile toe), it was found advisable to adopt the concept of $8 \mathrm{~B}$ above, and $4 \mathrm{~B}$ below the pile base suggested by Eslami and Fellenius (1997). Then, it will be interesting if we combine each part with its relative contribution (i.e, the upper region (a) with its relative contribution, $W_{\alpha}$ and the lower $(\beta)$ with its relative contribution, $W_{\beta}$ ). The average blow counts over the failure zone will be written as:

$$
\bar{N}_{b}=W_{\alpha} \cdot N_{\alpha}+W_{\beta} \cdot N_{\beta},
$$

where: $N_{\beta}$ is the corrected average blow counts within the lower zone; $N_{\alpha}$ is the corrected average blow counts within the upper zone. To determine the contribution of these zones, $W_{\alpha}$ and $W_{\beta}$, separate FE analyses are carried out in this study; the details are given below.

\subsection{Finite element modelling}

The commercial Software PLAXIS 2D (2011) is employed to evaluate the relative contribution of the zones

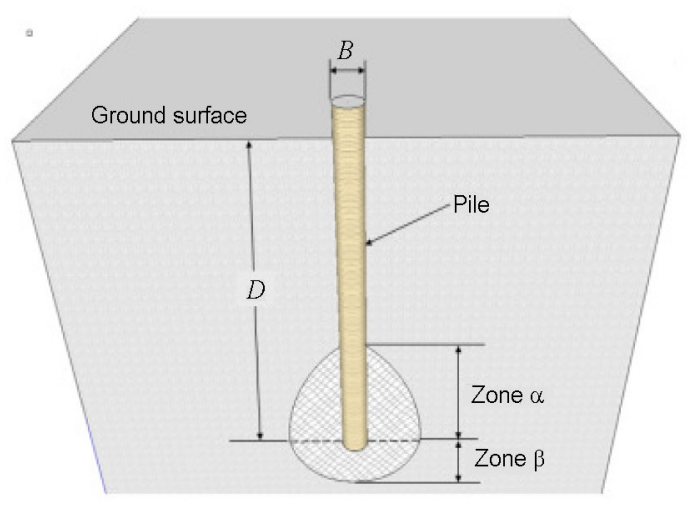

Fig. 2. Influence zone for averaging blows number near the pile base 


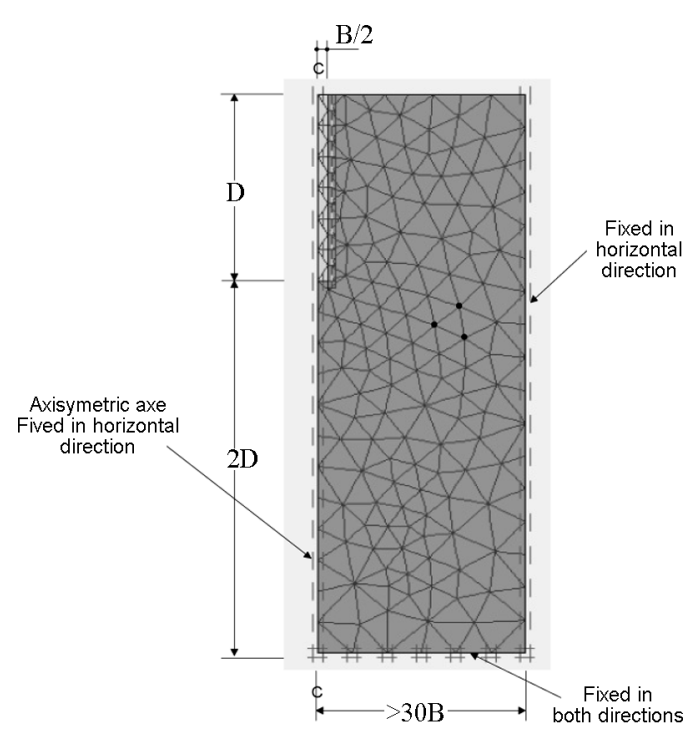

Fig. 3. Geometry and boundary conditions of the used numerical model

above and below the pile tip to the pile end-bearing capacity. The numerical model has been calibrated against Salgado and Lee (1999) model. To simulate Salgado and Lee model, an axisymmetric FE model is used to predict the behaviour of an axially loaded single vertical pile embedded in Tocino sand. The boundaries are selected at large distance such that there is minimal effect on the results (Azizi 2000) (Fig. 3). 15-node triangular elements, giving a fourth-order interpolation for displacements, are used for both the soil and pile clusters. The soil is modelled as an isotropic elastic perfectly plastic continuum with failure described by the Mohr Coulomb yield criterion. Material properties of the soil model are listed in in Table 1. The pile material was modelled as nonporous material with a linear elastic constitutive relationship requiring only two input parameters: young's modulus $\left(E_{\mathrm{p}}\right)$ and Poisson's ratio $\left(v_{\mathrm{p}}\right)$ (Table 2). An elastic-plastic model based on the Coulomb criterion is used to describe the soil-pile interface behaviour with an interface friction angle of $0.7 f$ (Stas, Kulhawy 1984).

The base resistance-base settlement curve obtained from the current study is compared to the corresponding curve of Salgado and Lee as shown in Figure 4. Although

Table 1. Material properties of the sand layer

\begin{tabular}{l|l}
\hline \multicolumn{2}{c}{ Soil properties } \\
\hline Drained state & Drained \\
\hline Relative density/soil state & $35 \% /$ medium \\
\hline Soil unit weight in $\mathrm{kN} / \mathrm{m}^{3}$ & 18 \\
\hline Poisson's ratio & 0.33 \\
\hline Internal friction angle in degree & 34.8 \\
\hline Dilatation angle in degree & 3 \\
\hline Young's modulus in $\mathrm{kPa}$ & $50 \times 10^{3}$ \\
\hline Friction angle of interface in degree & 23 \\
\hline
\end{tabular}

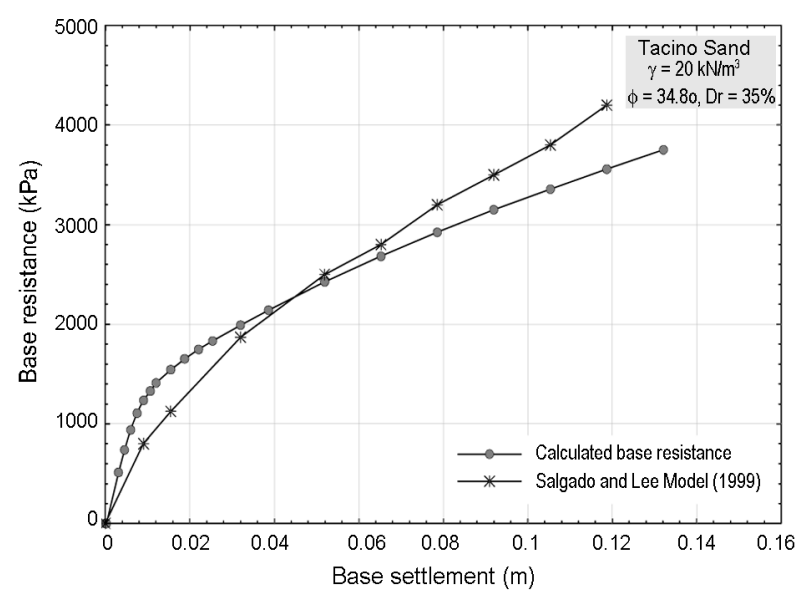

Fig. 4. Calibrated numerical model against Salgado and Lee (1999) model

the initial slope of the present load-settlement curve is larger than that of Salgado and Lee (1999), the present FE prediction seems to match reasonably well with the previous study up to a $0.11 \mathrm{~B}$ base settlement. However, with further increase in the base settlement, the present analysis underestimates the pile end-bearing resistance. The difference in the initial slopes may be attributed to the difference in soil modelling between the two studies. It worth noting that the ultimate load is defined in the current study as the pile load corresponding to a $0.1 B$ vertical settlement (Eurocode 7 2004). This settlement is, in fact, close to $0.11 \mathrm{~B}$ at which there is an agreement between the two load-settlement curves. In other words, the ultimate pile capacity adopted in the current study is in accordance with that obtained from Salgado and Lee (1999) results.

\subsection{Parametric study}

A comprehensive parametric study is performed to evaluate the contribution of the zones above and below the pile tip to its end-bearing resistance. The pile embedment depth $(D)$ and diameter $(B)$ were selected at $20 \mathrm{~m}$ and $0.6 \mathrm{~m}$, respectively. These properties refer to typical pile geometry. To model the soil profile, two homogenous sand layers (above and below pile tip) were considered. The effect of changing the mechanical properties (i.e, $N$ ) of the sand layers on the magnitude of the end-bearing

Table 2. Material properties of the pile

\begin{tabular}{l|l}
\hline \multicolumn{2}{c}{ Pile properties } \\
\hline Pile model & Linear elastic \\
\hline Pile type & Non porous \\
\hline Pile diameter in $\mathrm{m}$ & 0.6 \\
\hline Pile embedment in $\mathrm{m}$ & 20 \\
\hline Young's modulus in $\mathrm{kPa}$ & $30 \times 10^{6}$ \\
\hline Poisson's ratio & 0.3 \\
\hline Unit weight in $\mathrm{kN} / \mathrm{m}^{3}$ & 25 \\
\hline
\end{tabular}


resistance is investigated to reflect the relative contribution of the zones above and below the pile toe. Different values of the uncorrected standard penetration number, $N$ ranging from 5 to 40 for both sand layers was considered. The sand modulus of elasticity is estimated from the standard penetration number $N$ as follows:

- The uncorrected $N$ is first corrected according to Eqn (1) and then normalized with respect to overburden pressure according to Eqn (2) to obtain $N_{1(60)}$.

- Shear wave velocity, $V_{s}$ that is directly related to the soil shear modulus ( $G=\rho V_{s}^{2}$, where $r$ is the soil mass density), is evaluated from $N_{1(60)}$ based on Karray and Éthier (2012) relationship $\left(D_{50}=1 \mathrm{~mm}\right)$ :

$$
\frac{V_{s 1}}{N_{1}^{0.25}}=108.5
$$

where $V_{s 1}$ is the normalized shear wave velocity:

$$
V_{s}=\frac{V_{s 1}}{\left(P_{a} / \sigma_{v}^{\prime}\right)^{0.25}} \text {. }
$$

Finally, the modulus of elasticity $E_{s}$ can be calculated using:

$$
E_{s}=2 G(1+v)
$$

$E_{s}$ of all cases studied varies from 100 to $350 \mathrm{MPa}$, and $v$ was set at 0.33 .

\subsection{Evaluation of the contribution values of the zones above and below the pile tip}

Statistica Software v.10 is employed to analyse the results of the parametric study described above. Statistica has the opportunity to create a statistical model that represents the variability of the tip resistance, $q_{b}$ as a function of $W_{\beta}$, $W_{\alpha}, N_{\beta}, N_{\alpha}$ and the base resistance factor $(x)$ as indicated in Eqn (7) and, further allows us to numerically evaluate the coefficient of resistance at pile base $(x)$. The analysis results are given in Table 3 .

$$
q_{b}=x \cdot \bar{N}_{b}=x \cdot\left(W_{\beta} \cdot N_{\beta}+W_{\alpha} \cdot N_{\alpha}\right) .
$$

The obtained weights confirm that previous studies that neglect the contribution of the upper zone can lead

Table 3. Estimation of the relative contribution of the zones to the pile end-bearing capacity

\begin{tabular}{c|c|c|c|c}
\hline & \multicolumn{4}{|c}{ Model is: $q b(\mathrm{MPa})=x \cdot\left(W_{\beta} \cdot N_{\beta}+W_{\alpha} \cdot N_{\alpha}\right)$} \\
& \multicolumn{2}{|c}{ Level of confidence 95\% (alpha $=0.05)$} & $\mathrm{R}^{2}=0.76$ \\
\cline { 2 - 5 } & Estimate & $\begin{array}{c}\text { Standard } \\
\text { error }\end{array}$ & $\begin{array}{c}\mathrm{t} \text {-value } \\
\mathrm{df}=46\end{array}$ & $\mathrm{p}$-level \\
\hline$W_{\beta}$ & 0.60 & 0.017 & 17.83 & 0.0001 \\
\hline$W_{\alpha}$ & 0.40 & 0.013 & 14.56 & 0.0001 \\
\hline \begin{tabular}{c}
$\mathrm{MPa})$ \\
\hline
\end{tabular} & 0.457 & 0.015 & 15.80 & 0.0001 \\
\hline
\end{tabular}

to non-compliant estimates of the pile tip resistance. According to the current study, the upper zone contributes about $40 \%$ in mobilizing the pile end-bearing resistance. Eqn (3) can then be written as:

$$
\bar{N}_{b}=0.6 N_{\beta}+0.4 N_{\alpha}
$$

and therefore (see Table 3):

$$
q_{b}=0.457 \bar{N}_{b} \text { in } \mathrm{MPa} .
$$

It worth mentioning that the base resistance factor $(x)$ in Eqn (9) and Table 3 that equals to $0.457 \mathrm{MPa}$ is consistent with those found in the literature (e.g., Decourt 1982; Meyerhof 1976).

\section{Neural networks}

A neural network is a system composed of a set of neurons interconnected with each other. A certain disposition of the connection of these neurons produced a neural network model suitable for certain tasks. The Back Propagation Multilayer Perceptron (BPMLP) is the most popular neural network model often used, consisting of three adjacent layers, input, hidden and output (Dreyfus et al. 1994). To obtain some desired outputs, weights, which represent connection strength between neurons and biases, are adjusted using a number of training inputs and the corresponding target values. The network error, that is the difference between calculated and expected target patterns, then back propagated from the output layer to the input layer to update the network weights and biases. It arises during the learning process and it can be expressed in terms of mean square error (MSE) using:

$$
M S E=\frac{1}{p} \cdot\left(\sum_{j}\left(t_{j}-o_{j}\right)\right)^{2}
$$

where: $t_{j}$ is the target value of $j^{\text {th }}$ pattern, $O_{j}$ is the output value of $j^{\text {th }}$ pattern, and $P$ is the number of patterns. In addition, the absolute fraction of variance $\left(R^{2}\right)$ is also calculated using:

$$
R^{2}=1-\left(\frac{\sum_{j}\left(t_{j}-o_{j}\right)^{2}}{\sum_{j}\left(o_{j}\right)^{2}}\right) .
$$

The performance of a BPMLP relies heavily on its ability of generalization, which, in turn, depends on the data representation. An important feature of data representation is the de-correlation of these data. In other words, a set of data presented at a BPMLP should not consist of correlations between them because the correlated data reduce the distinctiveness of the representation of data, and therefore, introduce confusion to the model during the learning process and, thus, produces a BPMLP with a low ability to generalization for new data (Bishop 1994). This suggests the need to eliminate the correla- 
tion of data before they are presented at a BPMLP. This can be achieved by the application of PCA technique on all input data before training the BPMLP (Jolliffe 2002). This technique was utilized in this study and will be described in details below.

\section{Principal component analysis (PCA)}

The technique of PCA is a descriptive technique to study the dependencies between variables, for a description or a compact representation of these variables. Since 70 years, many researchers have used the PCA method as a tool for processes modelling from which a model can be obtained (e.g., Kresta et al. 1991; MacGregor, Kourti 1995). It was also successfully applied as a technique for reducing the dimensionality of ANN inputs in a variety of engineering applications (e.g., Harkat 2003; Kuniar, Waszczyszyn 2006; Shin et al. 2008; Boukhatem et al. 2012). Mathematically, PCA is an orthogonal projection technique that projects multidimensional observations represented in a subspace of dimension $m$ ( $m$ is the number of observed variables) in a subspace of lower dimension $(L<m)$ by maximizing the variance of the projections. The estimation of PCA parameters can be summarized in the calculus of eigenvalues and eigenvectors of the matrix $\Sigma$. From the spectral decomposition of this matrix it can be written as follows:

$$
\sum=p \wedge p^{T}=\sum_{i=1}^{m} \lambda_{i} \cdot p_{i} \cdot p_{i}^{T}
$$

where: $p_{i}$ is the $i^{\text {th }}$ eigenvector of $\Sigma$ and $\lambda_{i}$ is the corresponding eigenvalue.

The determination of the number $L$ which represents the number of eigenvectors corresponding to the dominant eigenvalues is very important. Many rules are proposed in the literature to determine the number of $L$ components to retain (Valle et al. 1999). In this study, we used the cumulative percentages of the total variance method. The percentage of variance is explained by the first $L$ components and is given by:

$$
P C V(L)=100 .\left(\frac{\sum_{j=1}^{l} \lambda_{j}}{\sum_{j=1}^{m} \lambda_{j}}\right) \% \text {. }
$$

\section{Development of the artificial neural network model}

\subsection{Database construction}

In this study, one ANN model, that deals with the two different types of pile installation, namely large- and lowdisplacement piles, is developed. The data used to calibrate and validate the ANN model are obtained from the literature and includes, respectively 247 and 168 static load tests on large- and low-displacement driven piles reported by different authors (Appendix 1). The conducted tests were performed at different non-cohesive sites. The large- and low-displacement tests include compression loading of steel, concrete and aluminium piles, driven statically (jacked-in) or dynamically into the ground.

\subsection{Model inputs and outputs}

- Nine factors affecting the pile capacity are presented in the ANN as potential model input variables. These include the embedment length $(D)$, two corrected blows numbers $\left(N_{\text {Shaft }}, \bar{N}_{b}\right)$, pile or shaft material (concrete, steel, and aluminium) (SM), and two pile classification (low- and large-displacement) (PC). To accurately account the wide variety of pile shapes, four diameters are considered which are; $B_{\text {ext }}$ (external or shaft diameter), $B_{\text {base }}$ (pile base diameter), $B_{\text {int }}$ (internal diameter) and $B_{\text {head }}$ (pile head diameter). Table 4 presents the ranges of the database constituents.

- It is fair to mention that the adopted averaging zone of the pile tip resistance described in Sections 1.3 and 1.4 would be unsatisfactory if the pile has large diameter compared to its embedment depth. However, as presented in Table 4, all the considered case has greater embedment compared to their diameters. It should be noted that the following conditions are applied to the input and output variables used in the current model:

- The considered driven piles are divided into two types and are translated from the text format into arbitrary numeric values (i.e., 2 for large-displacement and 3 for low-displacement piles). As shown in Table 4, the piles have different sizes and shapes with diameters ranging from $90 \mathrm{~mm}$ to $1800 \mathrm{~mm}$. This wide range in pile diameter may affect the behaviour of the pile accordingly they were classified into: small-diameter (diameter $<600 \mathrm{~mm}$ ) and largediameter piles (diameter $>600 \mathrm{~mm}$ ).

- The ultimate pile capacity $\left(Q_{t}\right)$ is defined in this study as the load corresponding to the plunging failure for the well-defined failure cases. For the cases where the failure load is not clearly defined, it is required to determine the failure load from the results of pile load tests through a unique criterion. According to Eurocode 7 (2004), Geotechnical Design-General rules, a small-diameter pile is considered to be failed if it experiences a settlement equal to $10 \%$ of its nominal dimension. On the other hand, the ultimate capacity of a large-diameter pile is accessed, following the recommendations of AASHTO (2000) and FHWA (1996), when the pile settlement $(S)$ equals to:

$$
S=(Q . L) /\left(E_{p} \cdot A_{p}\right)+B / 30,
$$

where: $Q$ is the test load; $L$ is the pile length; $A_{p}$ is the cross sectional area of pile and $E_{p}$ is the modulus of elasticity of the pile material. Figures 5 and 6 present the definition of the failure load for two recorded cases 


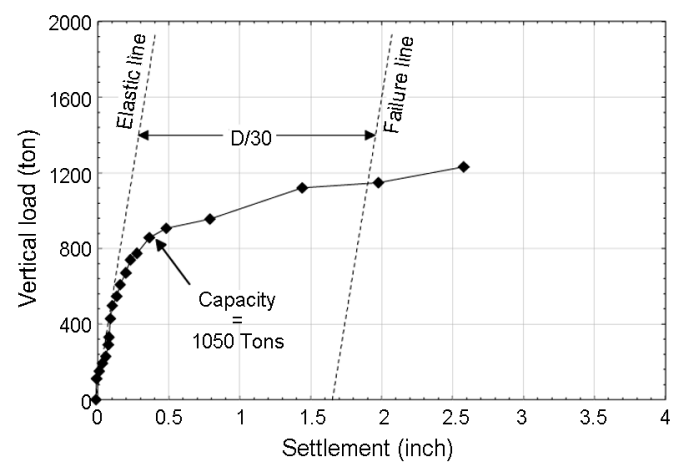

Fig. 5. Determining capacity of a driven concrete largediameter pile for the St. Georges Island Bridge Replacement Project $\left(B_{\text {ext }}=1.35 \mathrm{~m} ; B_{\text {int }}=1.15 \mathrm{~m}\right.$; sandy soil) (McVay et al. 2004)

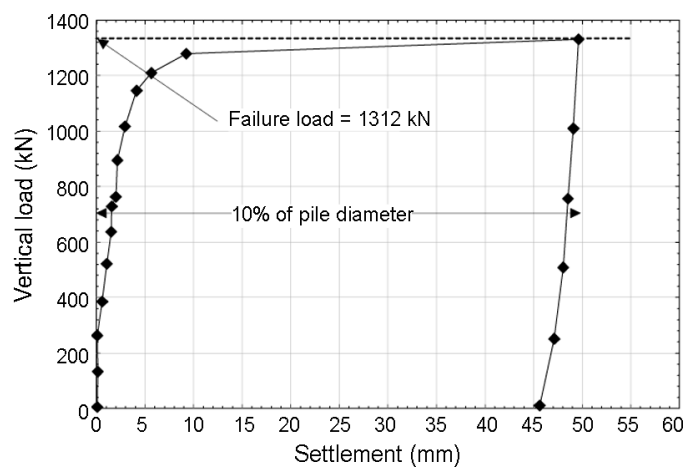

Fig. 6. Determining capacity of a driven concrete smalldiameter pile ( $B=0.5 \mathrm{~m}$; sandy soil) (Reiffsteck 2009)

Table 4. Ranges of the database constituents $\bar{N}_{b}^{b}$

\begin{tabular}{|c|c|c|c|c|}
\hline & \multicolumn{4}{|c|}{ Pile types } \\
\hline & \multicolumn{2}{|c|}{$\begin{array}{c}\text { Large } \\
\text { displacement }\end{array}$} & \multicolumn{2}{|c|}{ Low displacement } \\
\hline & Min & Max & Min & Max \\
\hline$B_{\text {ext }}(\mathrm{m})$ & 0.09 & 1.80 & 0.10 & 1.80 \\
\hline$B_{\text {int }}(\mathrm{m})$ & 0.00 & 1.75 & 0.00 & 1.75 \\
\hline$B_{\text {base }}(\mathrm{m})$ & 0.09 & 1.80 & 0.10 & 1.80 \\
\hline$B_{\text {head }}(\mathrm{m})$ & 0.09 & 1.80 & 0.10 & 1.80 \\
\hline$D(\mathrm{~m})$ & 3.00 & 61.00 & 2.00 & 86.00 \\
\hline$N_{\text {Shaft }}{ }^{\mathrm{a}}$ & 2.62 & 64.36 & 2.00 & 35.57 \\
\hline $\bar{N}_{b}^{b}$ & 5.35 & 101.00 & 2.00 & 71.50 \\
\hline $\begin{array}{l}\text { Shaft material } \\
1: \text { Steel } \\
2: \text { Concrete } \\
3: \text { Aluminum }\end{array}$ & 1 & 3 & 1 & 3 \\
\hline$Q_{t}(\mathrm{MN})$ & 0.08 & 33.74 & 0.08 & 31.00 \\
\hline Case number & \multicolumn{2}{|c|}{247} & \multicolumn{2}{|c|}{168} \\
\hline Total number & \multicolumn{4}{|l|}{415} \\
\hline
\end{tabular}

selected from the database presented in Appendix 1.

- Finally, and as the precedent, the pile materials is translated as, 1 for steel, 2 for concrete and 3 for aluminium.

\subsection{Data division}

There is no acceptable generalized rule to determine the size of the training and testing data for suitable training. In fact, this problem is network-dependent. In the majority of engineering applications, data division is customarily carried out on an arbitrary basis. To achieve the optimum division in this study, all the data sets were combined and shuffled using a cross validation method in which the data are be divided into three sets; training, testing and validation. The training set is used to adjust the connection weights, whereas the testing set is used to check the performance of the model at various stages of training and to determine when to stop training to avoid over-fitting. The validation set is used to estimate the performance of the trained network in the deployed environment. In total, $60 \%$ of the data (249 cases) are used for training, 20\% ( 83 cases) for testing and 20\% ( 83 cases) for validation.

\subsection{Methodology of implementation of PCA and ANN}

This section describes the steps taken to implement the PCA and the ANN approaches. The methodology is described in Figure 7. Two types of PCA data processing were implemented in two phases. The first phase is called Pre-PCA, which is responsible for pre-processing the training data matrix and eliminates correlations between them. The second is called Post-PCA, which is used to transform testing and validation data matrix according to its principal components. The implementation and simulation were performed using the MATLAB 7.5 (The Math Works 2007) functions of the neural networks toolbox.

\subsubsection{Pre-PCA phase}

According to Figure 7, the input data (Matrix C) were

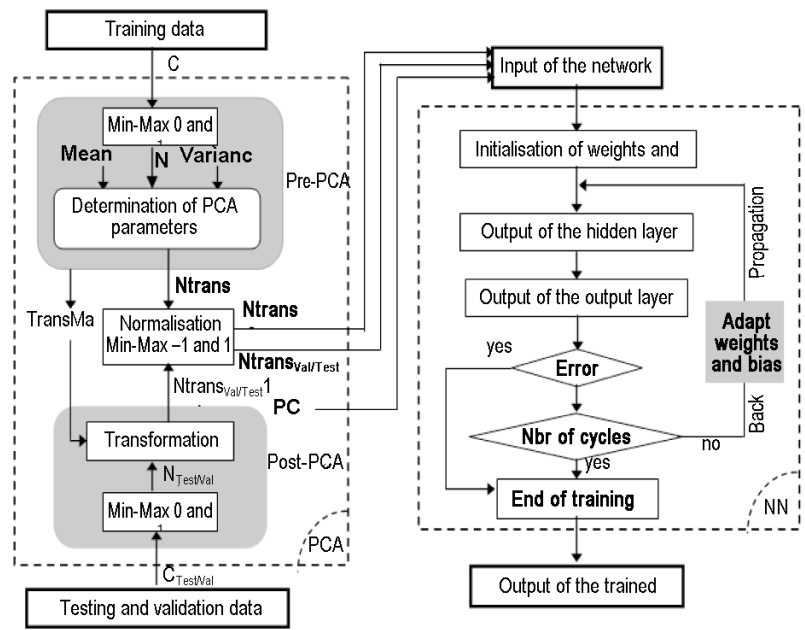

Fig. 7. Methodology of implementation of PCA and ANN 


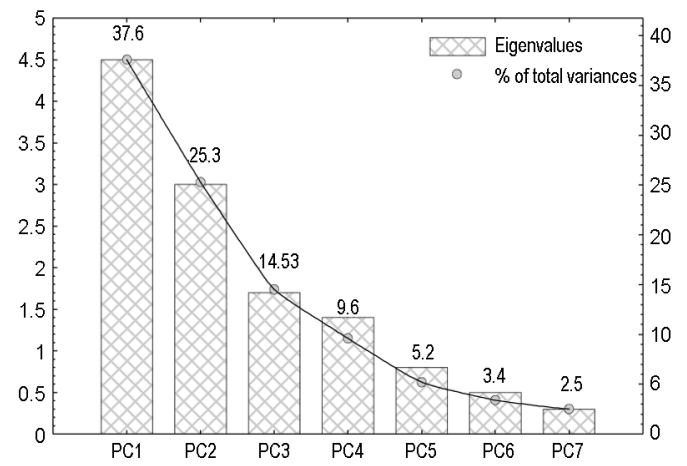

Fig. 8. Eigenvalues and contributions of components to the total variation

first normalized, so that they had zero and unity variances. Then, the PCA parameters (eigenvalues and eigenvectors) were estimated to calculate the principal components (PC) using the normalized data (Matrix N), the mean and variance values. This generates a transformation matrix (TransMat) and produces a transformed data (Ntrans) composed of orthogonal uncorrelated component (principal components). The matrix TransMat was then stored for later use during the phase of post-PCA. The uncorrelated components of matrix Ntrans were classified according to their variances. They were then passed to the ANN together with their corresponding target output values for a network training process based on a selected PC variance value. A representation of eigenvalues in terms of principal components for the model and the relative contribution of each component to the total variance of data are presented in Figure 8.

The nine (9) parameters of the row input matrix can be replaced by seven (7) first principal components based on a chosen PCV value. They were then introduced to the ANN inputs with their desired output. Many ANN were trained using different PCV values to determine the optimal percentage of this value of the total variance in the database. The best model is with PCV equal to $2 \%$ and seven principal components.

\subsubsection{Post-PCA phase}

During each training process of an ANN, validation and

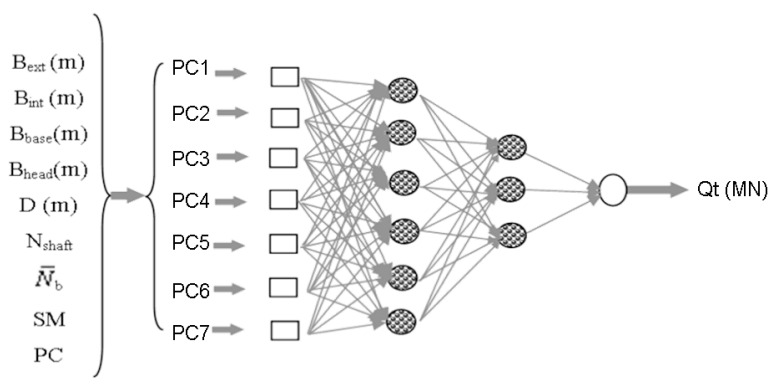

SM: Shaft Material, PC: Pile Classification; Qt: Pile Capacity

Fig. 9. Architecture of the developed ANN model for predicting the pile capacity

generalization performance on testing and validation data sets were evaluated. Each vector of validation or test data was post-processed with the post-PCA before it can be used an ANN to estimate or predict the output (Fig. 7). As in the pre-processing procedure, the validation or test data $C_{\text {val/test }}$ were normalized (mean 0 and variance 1 ). Then, the normalized data, $N_{\text {val/test }}$ were post-processed based on the correlation matrix TransMat (obtained during the pre-processing phase) to produce a new transformed data matrix Ntran $_{\text {val/test }}$ composed of reduced and uncorrelated data. The trained network used these reduced and uncorrelated data with its optimal weights obtained from training process to predict total pile capacity (ultimate load).

\subsubsection{Training, testing and network selection}

The developed model presented in Figure 9 was trained and tested with its data set for training, testing, and validation using the Bayesian regularization algorithm (MacKay 1992).

Once the desired errors have occurred, the output results obtained for the model was compared with the corresponding actual results. The comparison was made in terms of calculating the coefficient of determination MSE, $R^{2}$ and $P_{\text {value }}$. Generally, the calculation of $P_{\text {value }}$ was used to justify the significance of the studied relation (MacKay 1992). Training performances adopted in this application are summarized in Table 5. Figure 10 represents, respectively the training, as well as testing and validation results of the developed model.
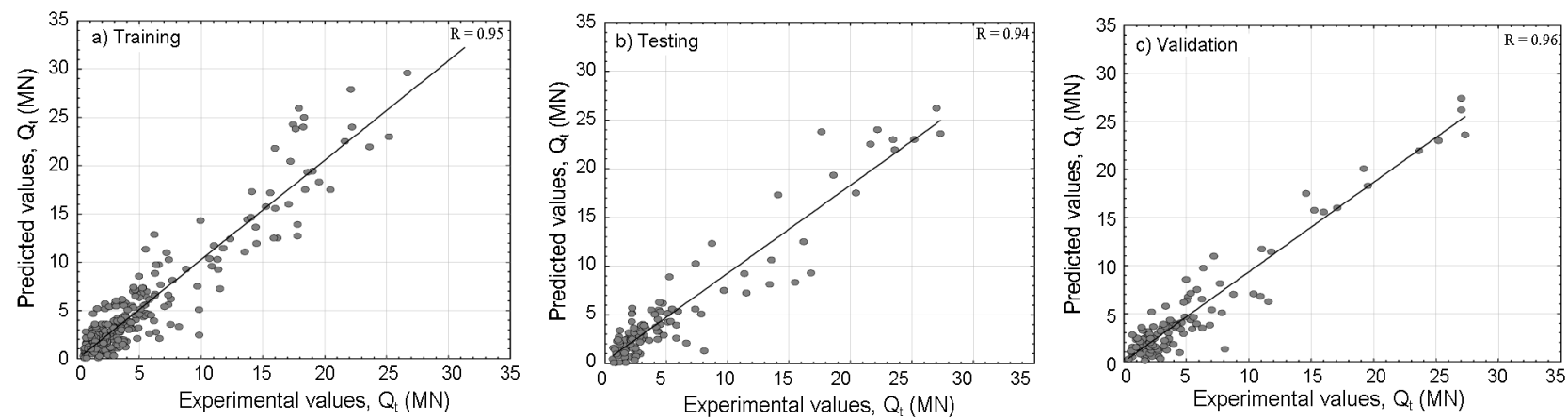

Fig. 10. Measured versus predicted pile capacity of the ANN model: (a) Training, (b) Testing, (c) Validation 
Table 5. Architecture and parameters of the developed model

\begin{tabular}{|c|c|c|c|c|c|c|c|c|c|c|c|c|c|c|}
\hline \multirow{2}{*}{$\begin{array}{l}\text { Input } \\
\text { (X) }\end{array}$} & PCA & & & ANN & & \multicolumn{8}{|c|}{ ANN Parameters } & \multirow{2}{*}{$\begin{array}{l}\text { Output } \\
\text { (Y) }\end{array}$} \\
\hline & & & \multicolumn{4}{|c|}{ With PCA } & \multicolumn{4}{|c|}{ Without PCA } & & & & \\
\hline \multirow{2}{*}{9} & PCC & $\mathrm{PCV}$ & N.PC & N.HL & N.NHL & $\mathrm{Mu}$ & MSE/N.ITR & $\mathrm{R}^{2}$ & $\mathrm{P}$ & $\mathrm{Mu}$ & MSE/N.ITR & $\mathrm{R}^{2}$ & $\mathrm{P}$ & \multirow{2}{*}{$\begin{array}{l}\text { Ultimate } \\
\text { Capacity } \\
\text { (MN) }\end{array}$} \\
\hline & 95.3 & 0.02 & 7 & 2 & $6 / 3$ & 0.005 & $0.009 / 30$ & 0.94 & $10^{-4}$ & 0.005 & $0.01 / 250$ & 0.89 & $10^{-4}$ & \\
\hline
\end{tabular}

Notes: PCC: Principal Component Contribution. N.HL: Number of Hidden Layers. N.NHL: Number of Neurons in each Hidden Layer. Mu: Momentum value. N.ITR: Number of Iterations or cycles. MSE: the training error of the network; $\mathrm{R}^{2}$ : Coefficient of determination. P: $\mathrm{P}_{\mathrm{value}}$

\subsubsection{Design formula of the ANN model}

The mathematical expression of the ANN model developed in this study can be written as:

$$
\begin{gathered}
Y=f_{\text {Tansig }}\left\{b_{0}+\sum_{k^{\prime}=1}^{h^{\prime}}\left[w_{k^{\prime}} \cdot f_{\text {Tansig }}\left(b_{h^{\prime} k^{\prime}}+\sum_{k=1}^{h} w_{k^{\prime} k} \cdot y_{k}\right)\right]\right\} \\
\mathrm{y}_{\mathrm{k}}=f_{\text {Tansig }}\left(b_{h k}+\sum_{i=1}^{m} w_{k i} \cdot X_{i}\right)
\end{gathered}
$$

where: $Y$ is the output of the model (the ultimate pile capacity $\left.Q_{t}\right) ; X_{i}$ is the model inputs; $w_{k^{\prime}}$ is the connection weight between $k$ 'th neuron of a hidden layer and the single output neuron; $b_{h k}$ is the bias at the $k^{\text {th }}$ neuron of the first hidden layer; $b_{h^{\prime} k^{\prime}}$ is the bias at $k^{\prime}$ th neuron of the second hidden layer; $h$ is the number of neurons in the first hidden layer; $h$ ' is the number of neurons in the second hidden layer; $w_{k i}$ is the connection weight between $i^{\text {th }}$ input variable and $k^{\text {th }}$ neuron of the first hidden layer; $w_{k^{\prime} k}$ is the connection weight between $k$ 'th neuron of the second hidden layer and $k^{\text {th }}$ neuron of the first hidden layer; $b_{0}$ is the bias at the output layer and $f_{\text {Tansig }}$ is the Tan sigmoid transfer function. More details of the weights and biases based on the trained ANN model are given in Appendix 2.

\section{Comparison of ANN model with available SPT-based methods}

To examine the accuracy of the low- and large- displacement pile model against available methods, the model is compared with four SPT-based methods currently used in practice. In fact, those current methods for calculating the pile capacity do not distinguish between low- and largedisplacement piles except Meyerhof's method (1976). The calculation results are displayed in Table 6 . The developed model is compared with the Meyerhof's method (1976), Shioi and Fukui's method (1982), Robert's method (1997) and the PHRI Standard's method (PHRI 1980). Optimal performance of a pile capacity prediction model is indicated three criteria:

- The first criterion is determined by carrying out a regression analysis to obtain the best fit line of predicted versus measured pile capacities. The neural network model has respectively, $Q_{f i t} / Q_{m}$ equal to 0.93 and 0.95 with $R^{2}=0.94$ and 0.95 for largeand low-displacement piles, which implies that the developed model gives the better values comparing with the others methods.

- The second criterion is determined by carrying out arithmetic calculations of mean $(\mu)$ and standard deviation $(\sigma)$. It can be seen that the developed model for large-displacement pile tends to underestimate

\begin{tabular}{|c|c|c|c|c|c|}
\hline \multirow[b]{2}{*}{ Methods } & \multicolumn{2}{|c|}{ Best fit calculations } & \multicolumn{2}{|c|}{ Arithmetic calculations } & \multirow{2}{*}{$\begin{array}{c}\text { Accuracy } \pm 25 \% \\
\text { Lognormal } \\
\end{array}$} \\
\hline & $Q_{f i t} / Q_{m}$ & $R^{2}$ & $\mu\left(Q_{p} / Q_{m}\right)$ & $\sigma\left(Q_{p} / Q_{m}\right)$ & \\
\hline \multicolumn{6}{|l|}{ Large-displacement pile } \\
\hline Neural network model & 0.93 & 0.95 & 0.94 & 0.28 & 78 \\
\hline Meyerhof (1976) & 0.92 & 0.84 & 0.90 & 0.30 & 58 \\
\hline PHRI Standard (1980) & 0.88 & 0.78 & 1.14 & 0.35 & 54 \\
\hline Shioi and Fukui (1982) & 0.51 & 0.26 & 0.78 & 0.27 & 39 \\
\hline Robert (1997) & 0.91 & 0.82 & 0.87 & 0.27 & 46 \\
\hline Abu Kiefa (1998) (ANN model) & - & 0.91 & - & - & - \\
\hline \multicolumn{6}{|l|}{ Low-displacement pile } \\
\hline Neural network model & 0.94 & 0.95 & 1.05 & 0.15 & 83 \\
\hline Meyerhof (1976) & 0.91 & 0.83 & 0.89 & 0.43 & 54 \\
\hline
\end{tabular}

Table 6. Performance of ANN model against available SPT-based methods and some computing intelligent models

Note: $Q_{f i t}$ - pile capacity of the best fit of predicted versus measured pile capacity; $Q_{p}-$ predicted pile capacity; $Q_{m}-$ measured pile capacity; $\mu$ - mean; $\sigma$-standard deviation. 

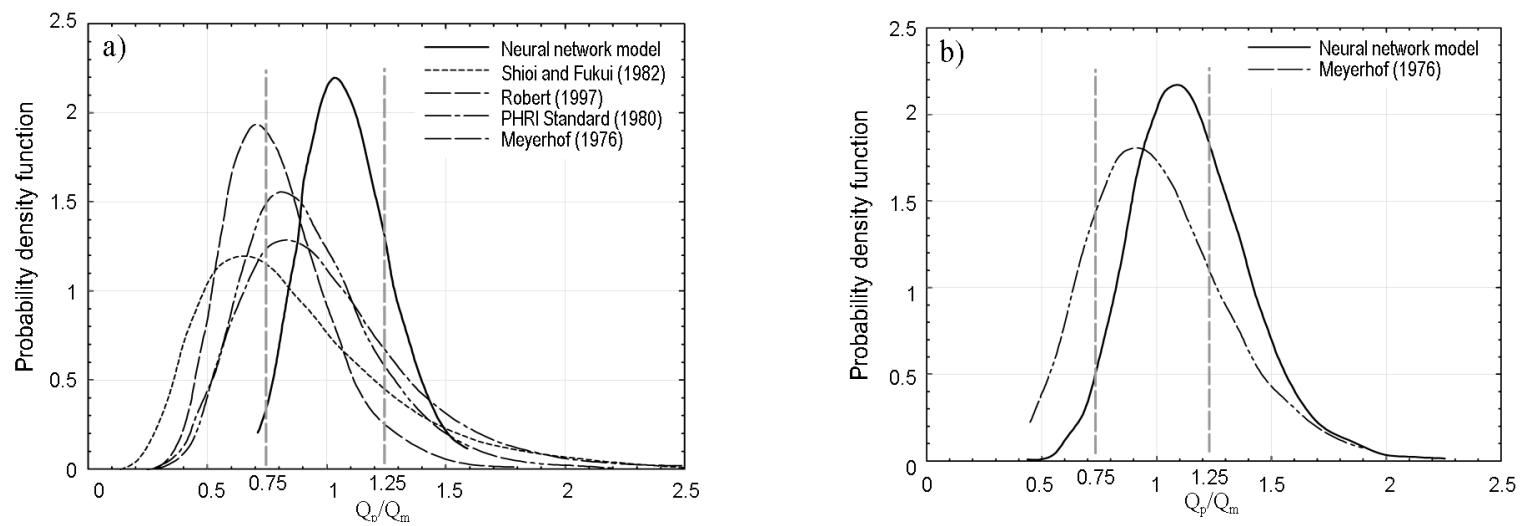

Fig. 11. Performance of ANN model against available SPT-based methods: (a) large-displacement piles, (b) low-displacement piles

the measured pile capacity by an average value of $6 \%$. For low-displacement pile, the model tends to overestimate the measured pile capacity by an average value of $5 \%$. This gives better performance when comparing with Meyerhof's (1976) method that tends to underestimate respectively the pile capacity with an average value of $10 \%$ and $11 \%$ for large-and low-displacement piles.

- The third criterion is evaluated by plotting the lognormal distributions of $Q_{p} / Q_{m}$ ratio of the remaining data for all methods (Fig. 11). The probability of predicting the pile capacity within $\pm 25 \%$ accuracy (P) is then obtained by calculating the area beneath the lognormal distribution within a range equal to $0.75 Q_{m} \leq Q_{p} \leq 1.25 Q_{m}$. Based on this criterion, the high probability implies a higher accuracy of the predict method. It can be seen that, the developed model is again ranked with the highest lognormal distribution probability values of $78 \%$ for large-displacement piles and of $89 \%$ for the low-displacement piles (Table 6).

\section{Parametric analysis based on the ANN results}

To examine the generalization ability of the developed ANN model, sensitivity analysis was carried out. A set of a hypothetical input that lies within the range of the training data was used to verify the response of the model to the variations of the input variables. The robustness of the model was determined by examining how well the predictions compare with available geotechnical knowledge and experimental data. The results of the sensitivity analysis are shown in Figures 12-14. It can be seen that the predictions of the pile capacity from the model agree well with what one would expect and with published experimental results in the sense that the pile capacity increases with the increase of the pile diameter $(B)$, embedment length $(D)$ and blows number $(N)$.

It can also be seen that for large-displacement piles, the concrete pile have a higher capacity than the closed-ended steel pipe pile and then, the aluminium pile (Figs 12a-14a). This can be attributed to the higher shaft resistance developed in the concrete pile as it has more roughness than the steel shaft (Alkroosh, Nikraz 2012). On the other hand, for low-displacement cases, the steel pile has a higher capacity than the concrete pile (Figs 12b-14b) as the majorities of the cases incorporated in this type (low-displacement) are $H$ or open-ended steel pipe piles in addition to some concrete piles. The developed shaft resistance in these types of steel piles are generally higher than that of the concrete piles. It is worth to mention that the results of the sensitivity analyses presented in Figures 12-14 provide an additional confirmation of the reliability of the developed ANN model.

\section{Statistical models based on neural network result}

To facilitate the use of the developed neural network mod$\mathrm{el}$, it is translated into a relatively simple design equations based on statistical models. The best statistical models
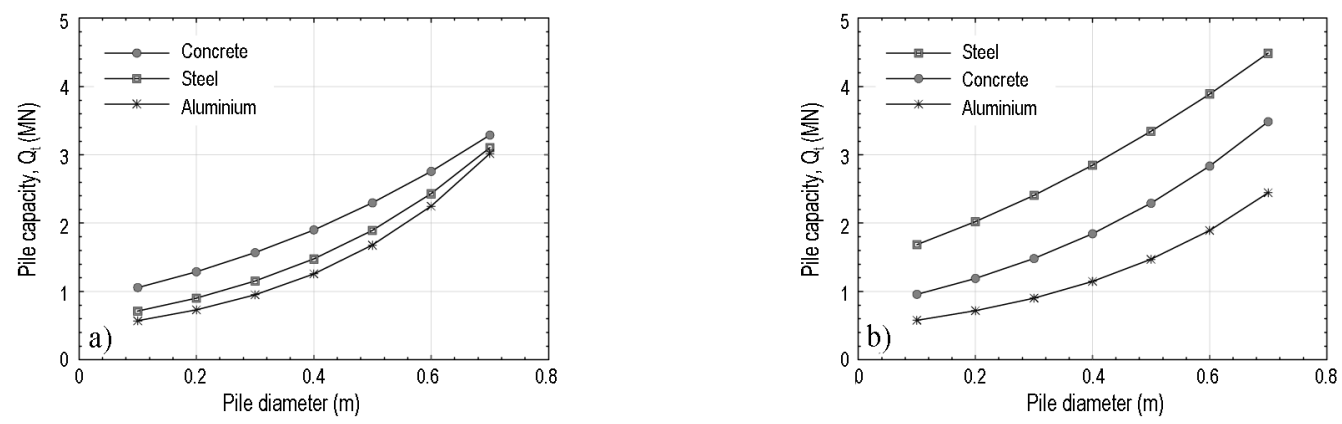

Fig. 12. Effect of pile diameter on pile capacity: (a) Large-displacement pile, (b) Low-displacement pile 

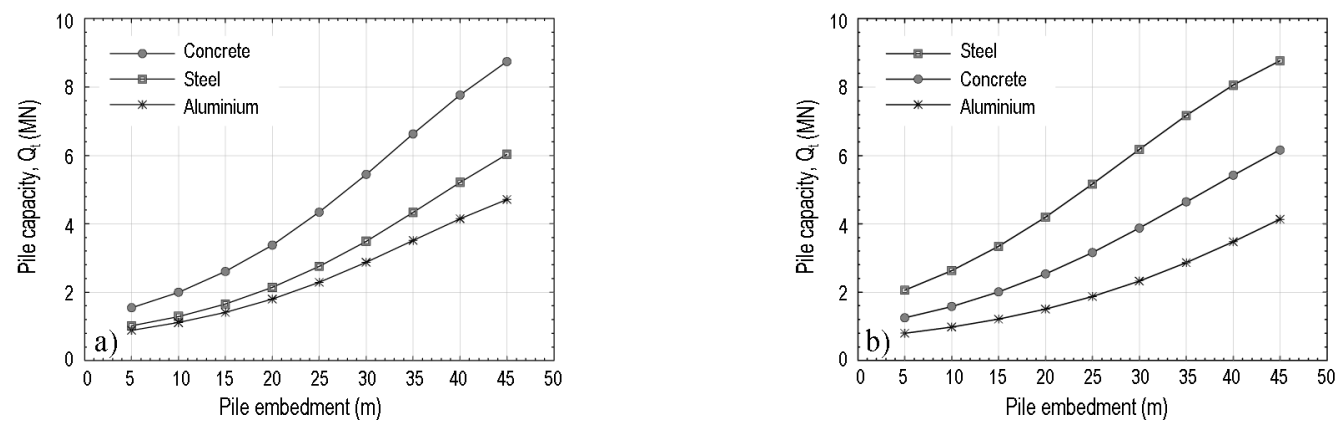

Fig. 13. Effect of pile embedment on pile capacity: (a) Large-displacement pile, (b) Low-displacement pile
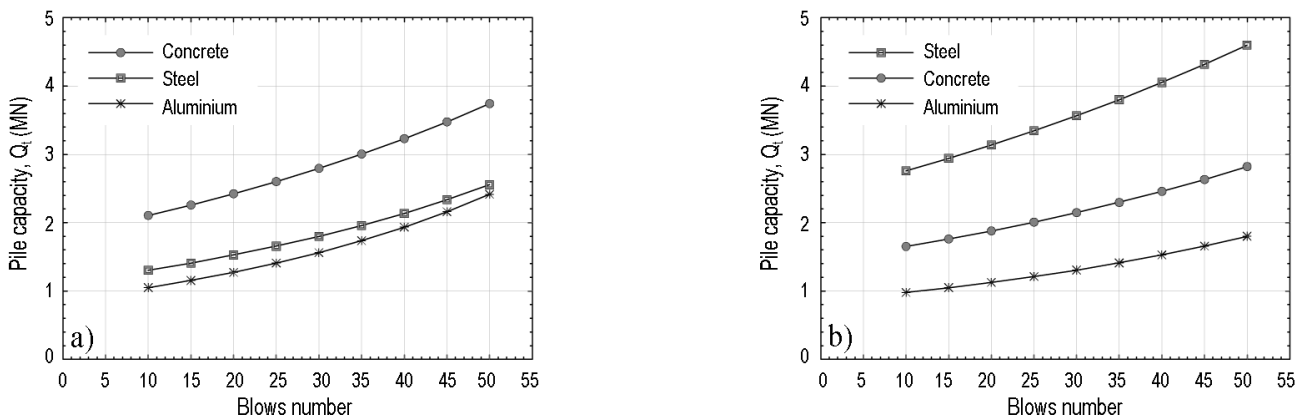

Fig. 14. Effect of blows number on pile capacity: (a) Large-displacement pile, (b) Low-displacement pile

retained to predict the pile capacity for both pile types based on neural network results were written according to the following functions:

a. For large-displacement piles (steel and concrete piles) with; $B_{\text {int }}=0 ; B_{\text {ext }}=B_{\text {base }}=B_{\text {head }}$ :

$Q t=b_{1} \cdot N_{\text {Shaft }} \cdot A s+b_{2} \cdot \operatorname{Exp}\left(b_{3} \cdot B_{\text {base }}+b_{4} \cdot D\right) \cdot \bar{N}_{b} \cdot A b$

b. For low-displacement piles:

- Concrete piles with; $B_{\text {int }}=0 ; B_{\text {ext }}=B_{\text {base }}=B_{\text {head }}$, the equation takes the following form:

$Q t=b_{1} \cdot N_{\text {Shaft }} \cdot A s+b_{2} \cdot \operatorname{Exp}\left(b_{3} \cdot B_{\text {base }}+b_{4} \cdot D\right) \cdot \bar{N}_{b} \cdot A b$

- Steel piles with: $B_{\text {int } 1} 10 ; B_{\text {ext }} B_{\text {base }}, B_{\text {ext }}=B_{\text {head }}$, the equation takes the following form:

$$
\begin{aligned}
Q t= & b_{1} \cdot N_{\text {Shaft }} \cdot A s+b_{2} \cdot \operatorname{Exp}\left(b_{3} \cdot B_{\text {ext }}+b_{4} \cdot B_{\mathrm{int}}+\right. \\
& \left.b_{5} \cdot B_{\text {base }}+b_{6} D\right) \cdot \bar{N}_{b} \cdot A b .
\end{aligned}
$$

The parameters $\left(b_{1}, b_{2}, b_{3}, b_{4}, b_{5}\right.$ and $\left.b_{6}\right)$ of these functions are adjusted and computed using the STATISTICA 7.1 software (Table 7).

\section{Conclusions}

In this paper, a comprehensive set of in-situ pile load test results collected from the literature has been utilized to develop an ANN model for capacity predictions of largeand low-displacement piles. In order to improve the predictive ability of the developed ANN model, the principal
Table 7. Parameters of the statistical models based on neural network results

\begin{tabular}{c|c|c|c|c}
\hline & \multicolumn{2}{|c|}{$\begin{array}{c}\text { Large-displacement } \\
\text { piles }\end{array}$} & \multicolumn{2}{c}{$\begin{array}{c}\text { Low-displacement } \\
\text { piles }\end{array}$} \\
\hline Coefficients & Concrete & Steel & Concrete & Steel \\
\hline$b_{1}$ & 0.0026 & 0.0015 & 0.0039 & $6.10^{-5}$ \\
\hline$b_{2}$ & 0.7000 & 0.7800 & $3.10^{-6}$ & 6.1900 \\
\hline$b_{3}$ & -3.0200 & -3.0200 & 7.3700 & 0.0670 \\
\hline$b_{4}$ & 0.0460 & 0.0460 & 0.1860 & 0.2400 \\
\hline$b_{5}$ & - & - & - & -4.9200 \\
\hline$b_{6}$ & - & - & - & 0.0200 \\
\hline$R^{2}$ & 0.86 & 0.90 & 0.92 & 0.96 \\
\hline$P$ value & $10^{-5}$ & $10^{-5}$ & $10^{-5}$ & $10^{-3}$ \\
\hline
\end{tabular}

component analyses (PCA) approach was applied. The incorporation of this technique led to the compression of the input data and the elimination of the correlation between them to predict effectively the pile capacity. The performance of the ANN model was examined against the most practically used SPT-based pile capacity prediction methods and some intelligent computing models. The results indicate that the developed model was capable of accurately predicting the ultimate capacity of both large- and low-displacement piles with high performance parameters $\left(R^{2}=0.95\right.$, Mean $\left.=1.05, \mathrm{SD}=0.28\right)$. The results suggest also that applying PCA method for data processing is very useful for improving the prediction performance of the ANN model. Moreover, the current study has confirmed that previous studies that neglect the 
contribution of the zone above the pile toe can lead to non-compliant estimates of the pile tip resistance.

\section{References}

AASHTO. 2000. LRFD bridge design specification. $2^{\text {nd }}$ ed. Washington, D.C., USA.

Abu Kiefa, M. A. 1998. General regression neural networks for driven piles on cohesionless soil, Journal of Geotechnical and Geoenvironmental Engineering 124(12): 1177-1185. https://doi.org/10.1061/(ASCE)10900241(1998)124:12(1177)

Ahangar-Asr, A.; Javadi, A. A.; Johari, A.; Chen, Y. 2014. Lateral load capacity modelling of piles in cohesive soils in undrained conditions: an intelligent evolutionary approach, Applied Soft Computing 24: 822-828.

https://doi.org/10.1016/j.asoc.2014.07.027

Alkroosh, I.; Nikraz, H. 2012. Predicting axial capacity of driven piles in cohesive soils using intelligent computing, Journal of Engineering Application of Artificial Intelligence 25(3): 618-627.

https://doi.org/10.1016/j.engappai.2011.08.009

Altaee, A.; Fellenius, B. H.; Evgin, E. 1992. Load transfer for piles in sand and the critical depth, Canadian Geotechnical Journal 30(3): 455-463. https://doi.org/10.1139/t93-039

Amini, A.; Fellenius, B. H.; Sabbagh, M.; Naesgaard, E.; Buehler, M. 2008. Pile loading tests at Golden Ears Bridge, in $61^{\text {st }}$ Canadian Geotechnical Conference, 21-24 September 2008, Edmonton. 8 p.

Azizi, F. 2000. Applied analyses in geotechnics. CRC Press. 776 p. https://doi.org/10.4324/9780203478738

Azizkandi, S. A.; Kashkooli, A.; Baziar, M. H. 2014. Prediction of uplift pile displacement based on cone penetration tests (CPT), Geotechnical and Geological Engineering 32(4): 1043-1052. https://doi.org/10.1007/s10706-014-9779-y

Bandini, P.; Salgado, R. 1998. Methods of pile design based on CPT and SPT results, in Proceedings of the $1^{\text {st }}$ International Conference on Site Characterization, 1998, Balkema, Rotterdam, 967-976.

Bellamine, F. H.; Elkamel, A. 2008. Model order reduction neural using network principal component analysis and generalized dimensional analysis, Engineering and Computer: International Journal of Computation Aid Engineering Software 25(5): 443-463. https://doi.org/10.1108/02644400810881383

Bishop, C. M. 1994. Neural networks and their applications, Revision of Scientific Instruments 65(6): 1803-1832. https://doi.org/10.1063/1.1144830

Boukhatem, B.; Kenai, S.; Tagnit-Hamou, A.; Ghrici, M. 2011. Application of new information technology on concrete: an overview, Journal of Civil Engineering and Management 17(2): 248-258. https://doi.org/10.3846/13923730.2011.574343

Boukhatem, B.; Kenai, S.; Tagnit Hamou, A.; Ziou, D.; Ghrici, M. 2012. A system for predicting concrete properties using neural networks (NN) with Principal Component analysis (PCA) technique, Computer and Concrete 10(6): 557-574. https://doi.org/10.12989/cac.2012.10.6.557

Bullock, P. J.; Schmertmann, J. H.; McVay, M. C.; Townsend, F. C. 2005. Side shear setup. I: test piles driven in Florida, Journal of Geotechnical and Geoenvironmental Engineering 131(3): 301-310. https://doi.org/10.1061/ (ASCE)1090-0241(2005)131:3(301)

Bustamante, M.; Christoulas, S.; Gianéselli, L.; Yannaros, H. 1985. Essais de chargement de pieux battus moulés sur le site de Kaminia (Athènes), Bulletin de Liaison du Laboratoire des Ponts et Chaussées 137: 5-15.
Byrne, B. 2005. Driven pipe piles in dense sand. Geomechanics Group, University of Western, Australia.

Campanella, R. G.; Sy, A.; Davies, M. P.; Roberston, P. K. 1989. Pile capacity prediction Event, in Symposium on Predicted and Observed Axial Behavior of piles. ASCE Geotechnical Special Publications Northwestern University of Illinois, USA, Vol. 23.

Carpentier, R. 1985. Pile foundation problems: recent developments, Belgian Geotechnical Volume Published for the 1985 Golden Jubilee of the International Society for Soil Mechanics and Foundation Engineering, 9-58.

Combarieu, O. 1976. Essais de chargement de pieux de grande longueur battus dans de la grave et de l'argile raide, Bulletin de Liaison du Laboratoire des Ponts et Chaussées 82: 5-15.

Coyle, H. M.; Castello, R. R. 1981. New design correlations for piles in sand, Journal of the Geotechnical Engineering Division 127(GT7): 965-986.

Dan Brown, M. 2002. Effect of construction on axial capacity of drilled foundations in piedmont soils, Journal of Geotechnical and Geoenvironmental Engineering 128: 967-973.

https://doi.org/10.1061/(ASCE)1090-0241(2002)128:12(967)

Das, B. M. 1984. Principal of foundation engineering. PWS Engineering Boston, Massachusetts.

De Nicola, A.; Randolph, M. F. 1999. Centrifuge modeling of pipe piles in sand under axial loads, Géotechnique 49(3): 295-318. https://doi.org/10.1680/geot.1999.49.3.295

Decourt, L. 1982. Prediction of the bearing capacity of piles based exclusively on N-value of the SPT, in Proceedings of the $2^{\text {nd }}$ European Symposium on Penetration Testing, 1982, Amsterdam, Netherlands, 29-34.

Deeks, A. D.; White, D. J.; Bolton, M. D. 2006. A comparison of Jacked, driven and bored piles in sand, in Proceedings of The $16^{\text {th }}$ International Conference on Soil Mechanics and Geotechnical Engineering (16ICSMGE), 13-16 September 2005, Osaka, Japan, 1685-1688.

Dreyfus, G.; Martinez, J. M.; Samuelides, M.; Gordon, M. B.; Badran, F.; Thiria, S.; Hérault, L. 1994. Réseaux de neurones - Méthodologie et application. Edition Eyrolles.

Durgunoglu, H. T.; Kulaç, H. F.; Ikiz, S.; Karadayilar, T.; Oge, C. E.; Olgun, C. G. 1996. A case study on determination of pile capacity using CPT. Foundation Engineering Consulting Report, Istanbul, Turkey.

Engin, H. K.; Binkgreve, R. B. J. 2009. Investigation of pile behavior using embedded piles, in Proceedings of The $17^{\text {th }}$ International Conference on Soil Mechanics and Geotechnical Engineering, 5-9 October 2009, Alexandria, Egypt, 1189-1192.

Eslami, A.; Fellenius, B. H. 1997. Pile capacity by direct CPT and CPTu methods applied to 102 cases histories, Canadian Geotechnical Journal 34(6): 886-904. https://doi.org/10.1139/t97-056

Eurocode 7. 2004. Geotechnical design-general rules. Thomas Telford, London.

Faizi, K.; Kalatehjari, R.; Nazir, A. S.; Rashid, A. 2015. Determination of pile failure mechanism under pullout test in loose sand, Journal of Central South University 22(4): 1490-1501. https://doi.org/10.1007/s11771-015-2666-8

Fellenius, B. H. 1989. Prediction of pile capacity, in Proceedings of the American Society of Civil Engineers, ASCE, Geotechnical Engineering Division, the 1989 Foundation Engineering Congress, Symposium on Predicted and $\mathrm{Ob}$ served Behavior of Piles 23: 293-302.

FHWA.1996. Design and construction of driven pile foundations. Report No. FHWA-HI-97-013, US Department of Transportation, Federal Highway Administration, Florida. 
Gavin, K.; Cadogan, D.; Twomey, L. 2008. Axial resistance of CFA piles in Dublin Boulder Clay, Geotechnical Engineering, Proceedings of the Institutions of Civil Engineers 6(GE4): 171-180. https://doi.org/10.1680/geng.2008.161.4.171

Goulet, G.; Jezequel, J. 1964. Comparaison entre les résultats de chargement statique d'un pieu et un groupe de pieux induits des essais géotechniques, Sols-Soils 11: 21-28.

Harkat, M. F. 2003. Détection et localisation de défauts par analyse en composantes principales: $\mathrm{PhD}$ dissertation. Institut National Polytechnique de Lorraine, Centre de Recherche en Automatique de Nancy.

Holeyman, A.; Debacher, P.; Dupont, E.; Legrand, C.; Menge, P.; Simon, G. 1997. Design of axially loaded piles - Belgian practice: design of axially loaded piles, in European practice. Editions De Cock \& Legrand \& Balkema, Rotterdam, 57-82.

Hsu, S. T. 2009. Axially loaded behavior of driven PC piles, in AIP Conference Proceedings, 30 November - 3 December 2009, Hong Kong - Macau, China, 1233.

Hussein, M. H.; Rausche, G.; Likins, G. E. 1993. Driving long precast concrete piles, in $14^{\text {th }}$ International Congress of the Precast Concrete Industry, 10-15 September 1993, Washington, D. C., USA. 8 p.

Hussein, M. H.; Woerner, W. A.; Sharp, M.; Hwang, H. 2006. Pile driveability and bearing capacity in high-rebound soils, in GeoCongress 2006: Geotechnical Engineering in the Information Technology Age, 26 February - 1 March 2006, Atlanta, Georgia, US, 1-4.

Ibrahim, A. M.; Atneisha, A.; Malik, I. 2013. Comparison study of pile foundation using EUROCODE 7 and working stress design approach, IOSR Journal of Engineering 3(8): 4-10. https://doi.org/10.9790/3021-03810410

Igoe, D. J. P.; Gavin, K. G. 2008. Field measurements of pipe pile base resistance in medium dense sand, in Proceedings of the $2^{\text {nd }} B G A$ International Conference on Foundations (ICOF), 24-27 June 2008, Dundee, Scotland, 149-158.

Igoe, D. J. P.; Gavin, K. G.; O’Kelly, B. C.; Byrne, B. 2013. The use of in-situ site investigation techniques for the axial design of offshore pile, Proceedings of the Fourth International Conference on Geotechnical and Geophysical Site Characterization (ISC 4), 18-21 September 2012, Pernambuco, Brazil. CRC Press, Taylor \& Francis Group, $1123-1129$.

Ishihara, K. 2010. Recent advances in pile testing and diaphragm wall construction in Japan, Geotechnical Engineering Journal of the SEAGS and AGSSEA 41(3): 1-43.

Iskander, M. 2011. Behavior of pipe piles in sand: plugging and pore-water pressure generation during installation and loading. Springer Series of Geomechanics and Geoengineering. Springer Berlin Heidelberg Edition. 250 p. https://doi.org/10.1007/978-3-642-13108-0

Ismael, N. F. 1999. Analysis of load tests on piles driven through calcareous desert sands, Journal of Geotechnical and Geoenvironmental Engineering 125(10): 1177-1185.

https://doi.org/10.1061/(ASCE)1090-0241(1999)125:10(905)

Ismail, A.; Jeng, D. S.; Zhang, L. L. 2013. An optimized product- unit neural network with a novel PSOBP hybrid training algorithm: applications to load-deformation analysis of axially loaded piles, Engineering Application of Artificial Intelligence 26(10): 2305-2314.

https://doi.org/10.1016/j.engappai.2013.04.007

Jardine, R. J.; Chow, F. C.; Matsumoto, T.; Lehane, B. M. 1998. A new design procedure of driven piles and its application to two Japanese clays, Soils and Foundations 38(1): 207-219. https://doi.org/10.3208/sandf.38.207

Jolliffe, I. T. 2002. Principal component analysis. $2^{\text {nd }}$ ed. New York: Springer. $488 \mathrm{p}$.
Karray, M.; Éthier, Y. 2012. Reply to the discussion by P. K. Robertson on "Influence of particle size on the correlation between shear wave velocity and cone tip resistance", Canadian Geotechnical Journal 49(1): 121-123. https://doi.org/10.1139/t11-101

Kate, J. 2005. Load-deformation behaviour of foundations under vertical and oblique loads: $\mathrm{PhD}$ thesis. James Cook University.

Kordjazi, A.; Pooya Nejad, F.; Jaksa, M. B. 2014. Prediction of ultimate axial load carrying of piles using vector machine based on CPT data, Computer and Geotechnics 55: 91-102. https://doi.org/10.1016/j.compgeo.2013.08.001

Kresta, J. V.; MacGregor, J. F.; Marlin, T. E. 1991. Multivariate statistical monitoring of process operating performance, Canadian Journal of Chemistry Engineering 69(1): 35-47. https://doi.org/10.1002/cjce.5450690105

Kulesza, R. L.; Fellenius, B. H. 2012. Design and testing of piles on a telecommunications project in Morocco: full scale testing in foundation design, in Proceedings of GeoCongress, 25-29 March 2012, Oakland, California, 452-470.

Kumpala, A.; Horpibulsuk, S. 2008. Prediction of undrained shear strength for hard silty clay Nakhon Ratchasima, Journal of Science and Technology 27(4): 348-355.

Kuniar, K.; Waszczyszyn, Z. 2006. Neural networks and principal component analysis for identification of building natural periods, Journal of Computation in Civil Engineering 20(6): 431-436.

https://doi.org/10.1061/(ASCE)0887-3801(2006)20:6(431)

MacGregor, J. F.; Kourti, T. 1995. Statistical process control of multivariate process, Control Engineering Practice 3(3): 403-414. https://doi.org/10.1016/0967-0661(95)00014-L

MacKay, D. J. C. 1992. Bayesian interpolation, Neural Computation 4(3): 415-447. https://doi.org/10.1162/neco.1992.4.3.415

McCammon, N. R.; Golder, H. Q. 1970. Some loading tests on long pipe piles, Géotechnique 20(2): 171-184. https://doi.org/10.1680/geot.1970.20.2.171

McVay, M. C.; Badri, D.; Hu, Z. 2004. Determination of axial pile capacity of prestressed concrete cylinder piles. Final Report No. 4910450487712. University of Florida, Civil and Coastal Engineering Department, Florida, USA.

Meyerhof, G. G.1976. Bearing capacity and settlement of pile foundations, Journal of Geotechnical Engineering 102(3): $1-19$.

Mohammad, H. B.; Azizkandi, S. A.; Kashkooli, A. 2015. Prediction of pile settlement based on cone penetration test results: an ANN approach, KSCE Journal of Civil Engineering 19(1): 98-106. https://doi.org/10.1007/s12205-012-0628-3

Mostafa, Y. E. 2011. Onshore and offshore pile installation in dense sand soils, Journal of American Science 7(7): 549-563.

Nguyen, T.; Hanna, A. M. 1991. A three dimensional model for single piles in sand, in Proceedings of the $4^{\text {th }}$ International Conference on Piling and Deep Foundations, 7-12 April 1991, Stresa, Italy, 421-429.

Norlund, R. L. 1963. Bearing capacity of piles in cohesionless soils, Journal of the Soil Mechanics and Foundations Division 89(3): 1-36.

Omer, J. R.; Delpak, R.; Robinson, R. B. 2010. A new computer program for pile capacity prediction using CPT data, Geotechnical and Geological Engineering 24: 399-426. https://doi.org/10.1007/s10706-005-2010-4

Omer, J. R.; Robinson, R. B.; Delpak, R.; Shih, J. K. C. 2003. Large scale pile tests in Mercia mudstone: data analysis and evaluation of current design methods, Geotechnical and Geological Engineering 21: 167-200. https://doi.org/10.1023/A:1024901730231 
Paik, K.; Salagado, R.; Lee, J.; Kim, B. 2003. Behavior of open and closed ended piles driven into sand, Geotechnical and Geoenvironmental Journal 129(4): 296-306.

https://doi.org/10.1061/(ASCE)1090-0241(2003)129:4(296)

PHRI. 1980. Technical standards for port and harbor facilities in Japan. Bureau of Ports and Harbors, Ministry of Transport, Japan.

Software PLAXIS 2D. 2011. PLAXIS, Finite element code for soil and rock analysis, Version 2011, Balkema.

Poulos, H. G. 1989. Pile behaviour - theory and application, Géotechnique 39(3): 365-415. https://doi.org/10.1680/geot.1989.39.3.365

Randolph, M. F.; Dolwin, J.; Beck, R. 1994. Design of driven piles in sand, Géotechnique 44(3): 427-448. https://doi.org/10.1680/geot.1994.44.3.427

Reiffsteck, P. 2009. Foundation design with Menard Pressumeter tests, in International Foundation Congress \& Equipment Expo'09 IFCEE, ASCE. Geotechnical Special Publication 186: 19-34.

Robert, Y. 1997. A few comments on pile design, Canadian Geotechnical Journal 34(4): 560-567. https://doi.org/10.1139/t97-024

Sakr, M. 2011. Installation and performance and characteristics of high capacity helical piles in cohesionless soils, Journal of the Deep Foundation Institute 5(1): 39-57. https://doi.org/10.1179/dfi.2011.004

Salgado, R.; Lee, J. 1999. Pile design based on cone penetration test results. Joint Transportation Research Program, Indiana Department of Transportation, Purdue University. 242 p. https://doi.org/10.5703/1288284313293

Salgado, R.; Zhang, Y. 2012. Use of pile driving analysis for assessment of axial load capacity of piles. Technical Reports, Purdue University (JTRP), Purdue e-Publication. https://doi.org/10.5703/1288284314671

Schneider, J. A.; Harmon, I. A. 2010. Analyzing drivability of open ended piles in very dense sands, Journal of the Deep Foundation Institute 4(1): 32-44. https://doi.org/10.1179/dfi.2010.003

Selby, K. G. 1970. Pile tests at Beech River, Canadian Geotechnical Journal 7(4): 470-493. https://doi.org/10.1139/t70-058

Shahin, M. A. 2014. Load settlement modeling of axially loaded drilled shafts using CPT based recurrent neural network, Soils and Foundations 54(3): 515-522. https://doi.org/10.1016/j.sandf.2014.04.015

Shariatmadari, N.; Eslami, A.; Karimpour-Fard, M. 2006. A new method for estimation the bearing capacity of piles based on SPT results, in 31st DFI Annual Conference on Deep Foundations, 4-6 October 2006, Washington, DC., USA.

Shin, S. W.; Yun, C. B.; Futura, H.; Popovics, J. S. 2008. Nondestructive evaluation of crack depth in concrete using PCA-compressed wave transmission function and neural networks, Experimental Mechanics 48(2): 225-231. https://doi.org/10.1007/s11340-007-9083-3

Shioi, Y.; Fukui, J. 1982. Application of N-value to design of foundation in Japan, in Proceeding of the $2^{\text {nd }} E S O P T$, 24-27 May 1982, Amsterdam, Netherlands, 1: 159-164.
Skempton, A. W. 1986. Standard penetration test procedures and the effects in sands of overburden pressure, relative density, particle size, aging and over consolidation, Géotechnique 36(3): 425-447. https://doi.org/10.1680/geot.1986.36.3.425

Stas, C. V.; Kulhawy, F. H. 1984. Critical evaluation of design methods for foundations under axial uplift and compression loading. Electrical Power Research Institute, Palo Alto California, Report EI-3771.

Tavenas, F. 1971. Load tests results on friction piles in sand, Canadian Geotechnical Journal 8(7): 8-22. https://doi.org/10.1139/t71-002

The Math Works. 2007. Neural Network for user with MATLAB 7.5. Prentice Hall.

Thompson, W. R. L.; Held, M.; Saye, S. 2009. Test pile program to determine axial capacity and pile setup for the Bioloxi Bay Bridge, Journal of the Deep Foundation Institute 3(1): 13-22. https://doi.org/10.1179/dfi.2009.002

Valle, S.; Weihua, L.; and Qin, S. J. 1999. Selection of the number of principal components: the variance of the reconstruction error criterion with a comparison to other methods, Industrial and Engineering Chemistry Research 38(11): 4389-4401. https://doi.org/10.1021/ie990110i

Viana da Fonseca, A. 2004. International prediction event on the behaviour of Bored, CFA, and Driven Piles in CEFEUP/ ISC'2 experimental site- 2003, in International Conference on Pile Behaviour, 2004, Porto, Portugal, 1-65.

White, D. J. 2003. Field measurements of SPT and pile base resistance in sand. Technical Report CUED /D- soils, TR327. University of Cambridge, UK.

White, D. J.; Sidhu, H. K.; Finlay, T. C. R.; Bolton, M. D.; Nagayama, T. 2000. Press- in piling: the influence of plugging on driveability, in $8^{\text {th }}$ International Conference of the Deep Foundations Institute, 2000, New York, USA, 299-310.

Xu, X.; Schneider, J. A.; Lehane, B. M. 2008. Cone penetration test methods for end bearing assessment of open and closed ended driven piles in siliceous sand, Canadian Geotechnical Journal 45(8): 1130-1141. https://doi.org/10.1139/T08-035

Yang, J.; Tham, L. G.; Lee, P. K. K.; Chan, S. T.; Yu, F. 2006. Behaviour of jacked and driven piles in sandy soil, Géotechnique 56(4): 245-259. https://doi.org/10.1680/geot.2006.56.4.245

Yu, F.; Yang, J. 2012. Base capacity of open ended steel pipe piles in sand, Journal of Geotechnical and Geoenvironmental Engineering 138(9): 1116-1128. https://doi.org/10.1061/(ASCE)GT.1943-5606.0000667

Zhang, L. M.; Ng, C. W. W.; Chan, F.; Pang, H. W. 2006. Termination criteria for jacked pile construction and load transfer in weathered soils, Journal of Geotechnical and Geoenvironmental Engineering 132(7): 819-829.

https://doi.org/10.1061/(ASCE)1090-0241(2006)132:7(819)

Zhussupbekov, A. Z.; Ashkey, A.; Bazilov, R.; Bazarbaev, D.; Alibekova, N. 2009. Geotechnical problems of new capital Astana (Kazakhstan), Proceeding of the International Geotechnical - Symposium, 2009, Russia. 
Appendix 1

Summary of recorded cases

Table A1. Summary of recorded cases (415 cases)

\begin{tabular}{|c|c|c|c|}
\hline Reference & Site location & Soil profile & $\begin{array}{l}\text { Pile type, } \\
\text { material }\end{array}$ \\
\hline Abu Kiefa (1998) & $\begin{array}{l}\text { Canada, Tokyo, Norway, } \\
\text { Sweden, The Netherlands, } \\
\text { Belgium, USA, Spain, } \\
\text { Scotland, Yugoslavia, China }\end{array}$ & Sandy soils & $\mathrm{A}, \mathrm{C} ; \mathrm{A}, \mathrm{S}$ \\
\hline Holeyman et al. (1997) & Belgium & Clay, Sand, Sandy loam & $\mathrm{A}, \mathrm{S} ; \mathrm{B}, \mathrm{S}$ \\
\hline Carpentier (1985) & Belgium & Clay, Sand, Sandy loam & $\mathrm{A}, \mathrm{S} ; \mathrm{B}, \mathrm{S}$ \\
\hline Combarieu (1976) & French & Limon, Sand, Gravel & $\mathrm{A}, \mathrm{S}$ \\
\hline Amini et al. (2008) & Canada & Sand, Silty sand & $\mathrm{A}, \mathrm{C}$ \\
\hline Deeks et al. (2006) & Japan & Silt, Sand and gravel, Silty sand & $\mathrm{B}, \mathrm{S}$ \\
\hline Bustamante et al. (1985) & Greece & Heterogeneous Remblai, Sand & $\mathrm{A}, \mathrm{C}$ \\
\hline Yang et al. (2006) & Hong Kong & Sand & $\mathrm{B}, \mathrm{C}$ \\
\hline Tavenas (1971) & Canada & Sand & $\mathrm{A}, \mathrm{C} ; \mathrm{A}, \mathrm{S} ; \mathrm{B}, \mathrm{S}$ \\
\hline Gavin et al. (2008) & Dublin City & $\begin{array}{l}\text { Fill, Alluvial gravel, Boulder clay, } \\
\text { Limestone }\end{array}$ & $\mathrm{B}, \mathrm{C}$ \\
\hline Ismael (1999) & Kuwait & Calcareous silty sand, Coarse sand & $\mathrm{A}, \mathrm{C}$ \\
\hline Combarieu (1976) & French & Limon, Sand, Gravel, Clay & $\mathrm{A}, \mathrm{C}$ \\
\hline $\begin{array}{l}\text { Kumpala and Horpibulsuk } \\
(2008)\end{array}$ & Thailand & Clayey sand, Silty sand & $\mathrm{A}, \mathrm{C}$ \\
\hline Omer et al. (2003) & USA & $\begin{array}{l}\text { Silty sand, Clay, sand and gravel, Mercia } \\
\text { mudstone }\end{array}$ & $\mathrm{A}, \mathrm{S} ; \mathrm{B}, \mathrm{S}$ \\
\hline Viana da Fonseca (2004) & Portugal & $\begin{array}{l}\text { Heterogeneous residual } \\
\text { granite(Saprolitic),Weathered granite soil }\end{array}$ & $\mathrm{A}, \mathrm{C} ; \mathrm{A}, \mathrm{S} ; \mathrm{B}, \mathrm{S}$ \\
\hline Fellenius (1989) & Canada & Sand, Clay & $\mathrm{A}, \mathrm{C} ; \mathrm{A}, \mathrm{S} ; \mathrm{B}, \mathrm{S}$ \\
\hline Campanella et al. (1989) & Illinois, USA & Sand, Clay, Silt & $\mathrm{A}, \mathrm{S} ; \mathrm{B}, \mathrm{S}$ \\
\hline McVay et al. (2004) & USA & Clay, Sand & $\mathrm{B}, \mathrm{C} ; \mathrm{B}, \mathrm{S}$ \\
\hline Eslami and Fellenius (1997) & III.USA & Sand & $\mathrm{B}, \mathrm{S} ; \mathrm{A}, \mathrm{S}$ \\
\hline McCammon and Golder (1970) & Finno, USA & Sand & $\mathrm{B}, \mathrm{S} ; \mathrm{B}, \mathrm{C}$ \\
\hline Randolph et al. (1994) & Canada & Clay, Sand, Silt & $\begin{array}{l}\mathrm{A}, \mathrm{S} ; \mathrm{A}, \mathrm{C} ; \mathrm{B}, \mathrm{S} ; \\
\mathrm{B}, \mathrm{C}\end{array}$ \\
\hline White (2003) & Canada & Sand & $\mathrm{A}, \mathrm{C}$ \\
\hline Omer et al. (2010) & Belgium & Sandy silt, Ledian sand & $\mathrm{B}, \mathrm{C}$ \\
\hline De Nicola and Randolph (1999) & Australia & Sand & $\mathrm{B}, \mathrm{Al}$ \\
\hline Mostafa (2011) & Different countries & Sand, Gravel, Silt & $\mathrm{B}, \mathrm{S}$ \\
\hline $\mathrm{Xu}$ et al. (2008) & Different countries & Sand & $\mathrm{A}, \mathrm{S} ; \mathrm{B}, \mathrm{S}$ \\
\hline Dan Brown (2002) & USA & Silty sand & $\mathrm{B}, \mathrm{C}$ \\
\hline Sakr (2011) & Canada & Sand & $\mathrm{A}, \mathrm{C}$ \\
\hline Kate (2005) & USA & Sand & $\mathrm{A}, \mathrm{C}$ \\
\hline Coyle and Castello (1981) & Canada & Sand & $\mathrm{A}, \mathrm{S} ; \mathrm{A}, \mathrm{C}$ \\
\hline Engin and Binkgreve (2009) & South Surra & Sand & $\mathrm{A}, \mathrm{C}$ \\
\hline Hussein et al. (2006) & Florida, USA & Sand, Silty sand, Clayey sand & $\mathrm{A}, \mathrm{C}$ \\
\hline Bullock et al. (2005) & Florida, USA & Sand, Silty sand, Clayey sand & $\mathrm{A}, \mathrm{C}$ \\
\hline Schneider and Harmon (2010) & USA & Sand & $\mathrm{B}, \mathrm{S}$ \\
\hline Salgado and Zhang (2012) & Indiana, USA & Gravelly sand, Clay and Sand & $\mathrm{B}, \mathrm{S}$ \\
\hline Byrne (2005) & Australia & Sand & $\mathrm{B}, \mathrm{S}$ \\
\hline Kulesza and Fellenius (2012) & Morocco, USA & Clay, Sand & $\mathrm{A}, \mathrm{S}$ \\
\hline
\end{tabular}


Continued Table A1

\begin{tabular}{|c|c|c|c|}
\hline Reference & Site location & Soil profile & $\begin{array}{l}\text { Pile type, } \\
\text { material }\end{array}$ \\
\hline Igoe and Gavin (2008) & County, Ireland & Gravelly clayey silt, Sand, Graval & $\mathrm{B}, \mathrm{S}$ \\
\hline Igoe et al. (2013) & County, Ireland & Gravelly clayey silt, Sand, Graval & $\mathrm{B}, \mathrm{S}$ \\
\hline Goulet and Jezequel (1964) & Belgium & Limon argileux, Clayey sand & $\mathrm{A}, \mathrm{C}$ \\
\hline Yu and Yang (2012) & USA & Clay, Sandy gravel, Sand & $\mathrm{B}, \mathrm{S}$ \\
\hline Jardine et al. (1998) & Japan & $\begin{array}{l}\text { Site1: Clay, Mudstone, } \\
\text { Site2: Clay, Gravel, Sand }\end{array}$ & $\mathrm{B}, \mathrm{S}$ \\
\hline Norlund (1963) & USA & Cohesionless soils & $\mathrm{A}, \mathrm{S} ; \mathrm{B}, \mathrm{S}$ \\
\hline Hsu (2009) & Taipei & Sand, Silty sand & $\mathrm{A}, \mathrm{C}$ \\
\hline White et al. (2000) & Japan & Silt, Sand and Gravel, Silty sand, Sand & $\mathrm{B}, \mathrm{S}$ \\
\hline Altaee et al. (1992) & Bagdad & Clayey silty sand, Sand and Silt & $\mathrm{A}, \mathrm{C}$ \\
\hline Hussein et al. (1993) & USA & $\begin{array}{l}\text { Site1: Silty sand, Clay, Silt, Sand, } \\
\text { Site2: Sand, Clayey sand, Sand, } \\
\text { site3: Sand, Clayey sand }\end{array}$ & $\mathrm{A}, \mathrm{C}$ \\
\hline Selby (1970) & Canada & Sand, Silt, Sandy silt & A, S \\
\hline Durgunoglu et al. (1996) & Istanbul, Turkey & Clay, Sand & $\mathrm{A}, \mathrm{C}$ \\
\hline Zhussupbekov et al. (2009) & Astana, Kazakhstan & Silty sand, Gravel, Sandstone & $\mathrm{B}, \mathrm{S}$ \\
\hline Reiffsteck (2009) & France & Clay and sand & $\mathrm{A}, \mathrm{C}$ \\
\hline Paik et al. (2003) & Indiana, USA & Gravelly sand, Clay and Silt & A, S; B, S \\
\hline Poulos (1989) & USA & Site1: Sand Site2: Clay & $\mathrm{B}, \mathrm{S} ; \mathrm{A}, \mathrm{C} ; \mathrm{B}, \mathrm{C}$ \\
\hline Zhang et al. (2006) & Germany & Weathered soils & $\mathrm{A}, \mathrm{C}$ \\
\hline Thompson et al. (2009) & Mississippi, USA & Sand, Clay & $\mathrm{A}, \mathrm{C}$ \\
\hline Ishihara (2010) & Japan & Sand & $\mathrm{A}, \mathrm{C}$ \\
\hline Ibrahim et al. (2013) & Germany & Silty clay, Silty sand & $\mathrm{A}, \mathrm{C}$ \\
\hline
\end{tabular}

Notes: Pile type: A - Large-displacement pile, B - Low-displacement pile,

Pile material: C - Concrete, Al - Aluminum, S - Steel,

";" indicates separator between cases in the same reference.

\section{Appendix 2}

Weights and biases of the developed ANN model for driven piles

$$
\begin{gathered}
\mathrm{W}_{1,1}=\left[\begin{array}{rrrrrrr}
-0.34925 & -0.03145 & -0.78142 & 0.55090 & -0.11344 & -0.09810 & -1.4787 \\
-0.84126 & -1.16260 & -0.78399 & -0.26030 & -0.33446 & -0.15453 & -1.6140 \\
-0.59594 & -0.35688 & 0.31650 & 0.14863 & 0.39201 & 0.35223 & -0.0278 \\
-0.03301 & -0.00712 & 0.36895 & 0.73412 & 0.13921 & 0.54558 & -0.2329 \\
-0.25597 & 0.47431 & -0.55695 & -0.63420 & -0.04814 & -0.20326 & 0.3080 \\
-0.99513 & 0.87478 & -0.96469 & -0.00994 & -0.13316 & -0.40996 & 0.7307
\end{array}\right] ; \\
\mathrm{W}_{2,1}=\left[\begin{array}{rrrrrr}
-0.16968 & -0.18391 & 0.27724 & 0.24868 & -0.034372 & -0.22083 \\
1.31220 & -1.04450 & 0.50417 & -0.23313 & -0.29225 & -1.01850 \\
-0.51967 & 1.10670 & 0.36711 & 0.54419 & -0.61744 & 0.12682
\end{array}\right] ;
\end{gathered}
$$




$$
\begin{aligned}
& \mathrm{b}_{1}=\left[\begin{array}{r}
-0.60350 \\
1.01670 \\
-0.06460 \\
0.47244 \\
-0.58480 \\
0.77294
\end{array}\right] ; \\
& \mathrm{b}_{2}=\left[\begin{array}{r}
-0.75310 \\
0.02006 \\
-0.58796
\end{array}\right] ; \\
& \mathrm{b}_{3}=[-0.68829] .
\end{aligned}
$$

Amel BENALI. He is a PhD student in civil engineering department at University of science and technology of Houari Boumediene, Algiers, Algeria, where she also obtained her BS and Master degrees in civil engineering in 1998 and 2002, respectively. She also works as a teacher and a researcher at University of Khemis Milana. She took the initiative of the establishment a civil engineering sector in the University of Khemis Miliana Algeria. In fact, she is the Head of the civil engineering branch at the University of Khemis Miliana.

Bakhta BOUKHATEM. He is a postdoctoral researcher at the Civil Engineering Department, University of Sherbrooke, Canada; she is an associate Professor at the Civil Engineering Department, University of Chlef, Algeria. Her research interests include the application of soft computing techniques to civil engineering problems, especially predicting properties and durability performances of concrete with additives using neural network.

Mahmoud N. HUSSIEN. He graduated from Kyoto University, Japan in 2011. During his PhD, Dr Hussien was focusing on studying the behavior of pile foundations at extensive nonlinearity induced in the ground, such as for liquefaction or soil-pile gap formation. $\mathrm{He}$ is an assistant professor at the Civil Engineering Department, Assiut University, Egypt. As a postdoctoral fellow at Sherbrooke University, Dr Hussien has been moving into new research areas. In addition to topics in mechanical behavior of granular soils, He was pursuing research in shear wave velocity measurements using new laboratory technique (P-RAT) as well as developing correlations between shear wave velocity of soils and their penetration resistances. Dr Hussien research efforts have been reported in more than 50 published journal and conference papers.

Ammar NECHNECH. He graduated from the Polytechnic, France in 1990; he began his work as a teacher at the Department of Civil Engineering, University of Science and Technology in Algiers, Algeria in 1993. He initiated the geotechnical laboratory in collaboration with a group of teachers. Prof. Nechnech is the Vice Dean of the faculty of Civil Engineering since 2004, and a professor since 2013.

Mourad KARRAY. He obtained his PhD grade in civil engineering from Université de Sherbrooke in 1999. He joined the civil engineering department at the same University in 2005 as an assistant professor. Mourad Karray is a full professor since June 2015. His research activities focus on the dynamic behavior of soils, liquefaction studies, and soil-structure interaction problems. Prof. Karray is also concerned with methods of soil characterization based on Rayleigh waves as well as measurement of shear wave velocity and degradation curves $\mathrm{G} / \mathrm{G}_{\max }$ in the laboratory. His work has given place to the publication of more than 80 scientific papers. 